\title{
First records of aphid-pathogenic Entomophthorales in the sub-Antarctic archipelagos of Crozet and Kerguelen
}

\author{
Bernard Papierok, ${ }^{1}$ Charles-Antoine Dedryver ${ }^{2} \&$ Maurice Hullé ${ }^{2}$ \\ 1 Pasteur Institute, 25 et 28, rue du Docteur Roux, FR-75015 Paris, France \\ 2 Institute for Genetics, Environment and Plant Protection, French National Institute for Agricultural Research, Domaine de la Motte, FR-35653 Le Rheu, \\ France
}

\section{Keywords}

Natural enemies; introduced species; biological invasion; colonization;

Zygomycetes; parasitism.

\section{Correspondence}

Maurice Hullé, Institute for Genetics, Environment and Plant Protection, French National Institute for Agricultural Research, Domaine de la Motte, FR-35653 Le Rheu, France. E-mail: maurice.hulle@rennes.inra.fr

\begin{abstract}
Since the 20th century, the sub-Antarctic islands have suffered an increasing number of biological invasions. Despite the large number of publications on this topic, there is a lack of knowledge on parasitism rates of invasive species and on the role of parasites and pathogens to regulate their populations. Six aphid species have been introduced in the archipelagos of Crozet (Île de la Possession, $\left.46^{\circ} 25^{\prime} \mathrm{S}-51^{\circ} 51^{\prime} \mathrm{E}\right)$ and Kerguelen $\left(49^{\circ} 21^{\prime} \mathrm{S}-70^{\circ} 13^{\prime} \mathrm{E}\right)$. Five of these species were found infected by entomopathogenic fungi of the order Entomophthorales. All these fungal species are cosmopolitan. Conidiobolus obscurus and Entomophthora planchoniana were the most frequently observed on Île de la Possession and in Archipel des Kerguelen, respectively. This is the first report of pathogenic fungi of aphids on the sub-Antarctic islands. We discuss these results in the light of our current knowledge of these insect pathogens. Their introduction by aphids surviving on plants during transportation is the most likely hypothesis to explain their presence on these remote islands.
\end{abstract}

As insular ecosystems in isolated and severe climatic environments, the sub-Antarctic archipelagos of Crozet and Kerguelen provide a unique field to address questions regarding invasive species in relation to increasing human impact and climate change (Gaston et al. 2002; Chown et al. 2005; Frenot et al. 2005; Chown et al. 2008). These remote islands have a cold oceanic climate and a depauperate native fauna and flora. Whalers and sealers were the main visitors during the 19th century and may be responsible for the first biological introductions. Kerguelen was increasingly visited from the beginning of the 20th century, whereas for Île de la Possession, in the Archipel Crozet, the increase in visits began in the mid20th century (Frenot et al. 2001; Lebouvier \& Frenot 2007). As sub-Antarctic islands, their food webs are poorly developed, with a high number of decomposers and very few herbivores, predators and parasites (Crafford et al. 1986; Chown et al. 1998; Vernon et al. 1998; Convey 2001). The success of invasive species in their new habitats can be explained at least in part by reduced control by natural enemies such as predators, pathogens and parasites - the enemy release hypothesis (Colautti et al.
2004; Liu \& Stiling 2006)-but also by their own biological traits, such as dispersal, fitness and so on (Hayes $\delta$ Barry 2008). However, there is a lack of knowledge about parasitism rates of invasive species and the role of parasites and pathogens in regulating their populations (Torchin et al. 2003; Prenter et al. 2004; Dunn et al. 2012).

Six species of aphids (Hemiptera, Aphididae) are known to occur on Île de la Possession and in Archipel des Kerguelen (Remaudière \& Etienne 1988; Hullé, Pannetier, Maurice et al. 2003): Aulacorthum solani (Kaltenbach), Macrosiphum euphorbiae (Thomas), Myzus ascalonicus Doncaster, Myzus ornatus Laing, Myzus persicae (Sulzer) and Rhopalosiphum padi (L.). These species are cosmopolitan and are understood to have been introduced within the last 80 years (Hullé, Pannetier, Simon et al. 2003). Myzus ascalonicus is the most invasive (Hullé, Pannetier, Simon et al. 2003; Hullé 2012). This generalist feeder has colonized both introduced and native plants belonging to 14 families, and has spread widely, preferentially along the littoral zone and below $100 \mathrm{~m}$ above sea level (Hullé, Pannetier, Simon et al. 2003). To understand major biological traits that influence colonization success by 
these cosmopolitan and polyphagous aphids in such subAntarctic environments, studies were carried out starting from the end of the 1990s. Host plant range, spatial and altitudinal distribution of aphids, their genetic variability, their role in the transmission of plant viruses and the vulnerability of native communities were especially investigated (Delmotte et al. 2001; Delmotte et al. 2003; Hullé, Pannetier, Maurice et al. 2003; Hullé, Pannetier, Simon et al. 2003; Lebouvier et al. 2011; Hullé 2012; Svanella-Dumas et al. 2013). Aphids killed by fungi of the order Entomophthorales (Zygomycetes) sensu Keller (2007) were first observed (by MH) in 2001 on Île de la Possession and in Archipel des Kerguelen, although the presence of natural enemies was not mentioned in the literature.

The present contrizbution compiles observations of aphid-pathogenic fungi in Archipel des Kerguelen and on Île de la Possession and discusses these data in the framework of our current knowledge on these insect pathogens and invasion biology.

\section{Material and methods}

Archipel des Kerguelen $\left(49^{\circ} 21^{\prime} \mathrm{S}-70^{\circ} 13^{\prime} \mathrm{E}, 7200 \mathrm{~km}^{2}\right)$ and Île de La Possession $\left(46^{\circ} 25^{\prime} \mathrm{S}-51^{\circ} 51^{\prime} \mathrm{E}, 150 \mathrm{~km}^{2}\right)$ in the Archipel Crozet are both in the sub-Antarctic area of the Southern Indian Ocean. Their mean annual temperatures are $4.85^{\circ} \mathrm{C}$ (Météo-France, 1951-2014 records) and $5.52^{\circ} \mathrm{C}$ (Météo-France, 1970-2014 records), respectively; little seasonal variation is recorded. The major climatic difference between these two archipels is rainfall: the total annual rainfall is $2400 \mathrm{~mm}$ on Île de la
Possession and varies from more than $3200 \mathrm{~mm}$ in the western part of Archipel des Kerguelen to less than $800 \mathrm{~mm}$ in the eastern part.

Entomophthorales-killed aphids were searched for during the austral growing seasons (December-May) in 2001/02 (Île de La Possession only) and 2011/12 and 2012/13 (Île de La Possession and Archipel des Kerguelen) at locations routinely used for botanical and entomological studies: Base Alfred Faure, Baie Américaine, Crique du Sphinx, Crique de Noël and Baie du La Pérouse on Île de la Possession (Fig. 1); and Base de Port-aux-Français, Île Haute, Île Mayes, Île aux Cochons and Île Verte in Archipel des Kerguelen (Fig. 2). Such aphids can be recognized by their peculiar brownish colour and, sometimes, their fixation on the substrate through fungal structures called rhizoïds or a layer of sporulating structures covering the body. When cadavers were found in aphid colonies, they were processed as follows to confirm the fungal nature of the infection and to identify the etiological agent. Leaves bearing colonies were cut out and placed in containers not completely closed, to prevent the atmosphere from becoming saturated. Back at the laboratory, leaves were observed with a binocular microscope. Aphids killed by Entomophthorales were gently removed from the leaf using forceps, and placed on a moistened piece of filter paper. That moistened piece was then attached to the inside of a Petri dish and the lid was inverted on slides to collect conidia forcibly discharged from cadavers. Following collection of conidia, slides were kept in dry conditions and corresponding cadavers stored in ethanol $70 \%$. For observation of conidia, the slides were mounted in cotton blue in

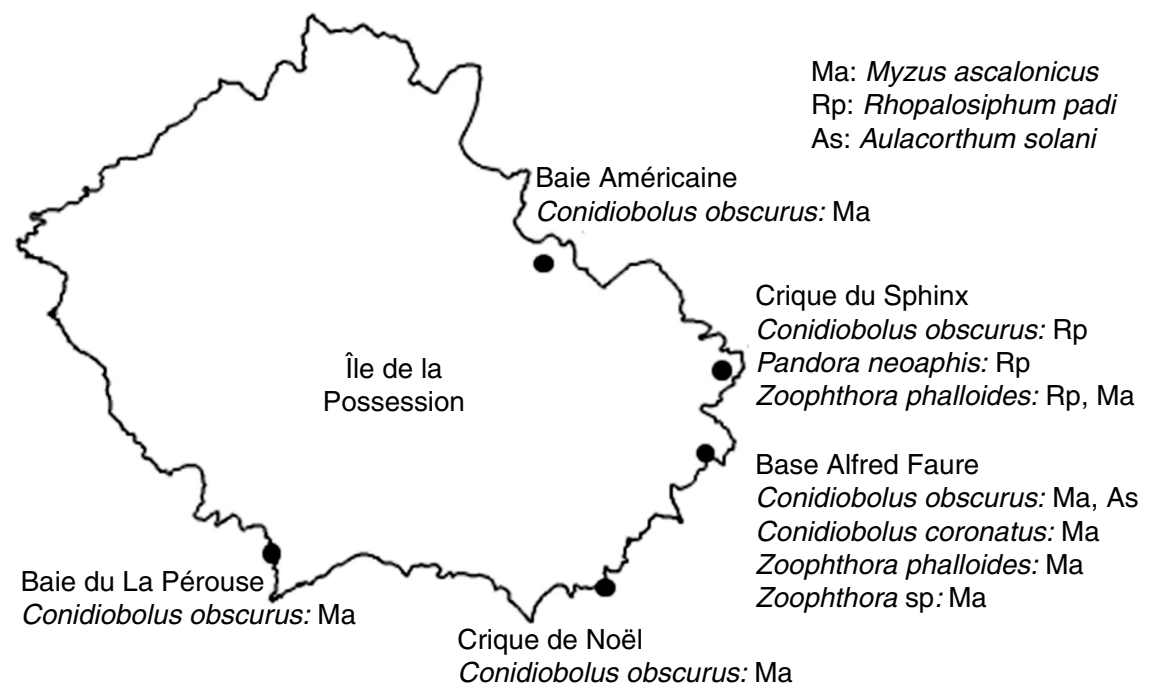

Fig. 1 Distribution of Entomophthorales on île de la Possession (Archipel Crozet). 


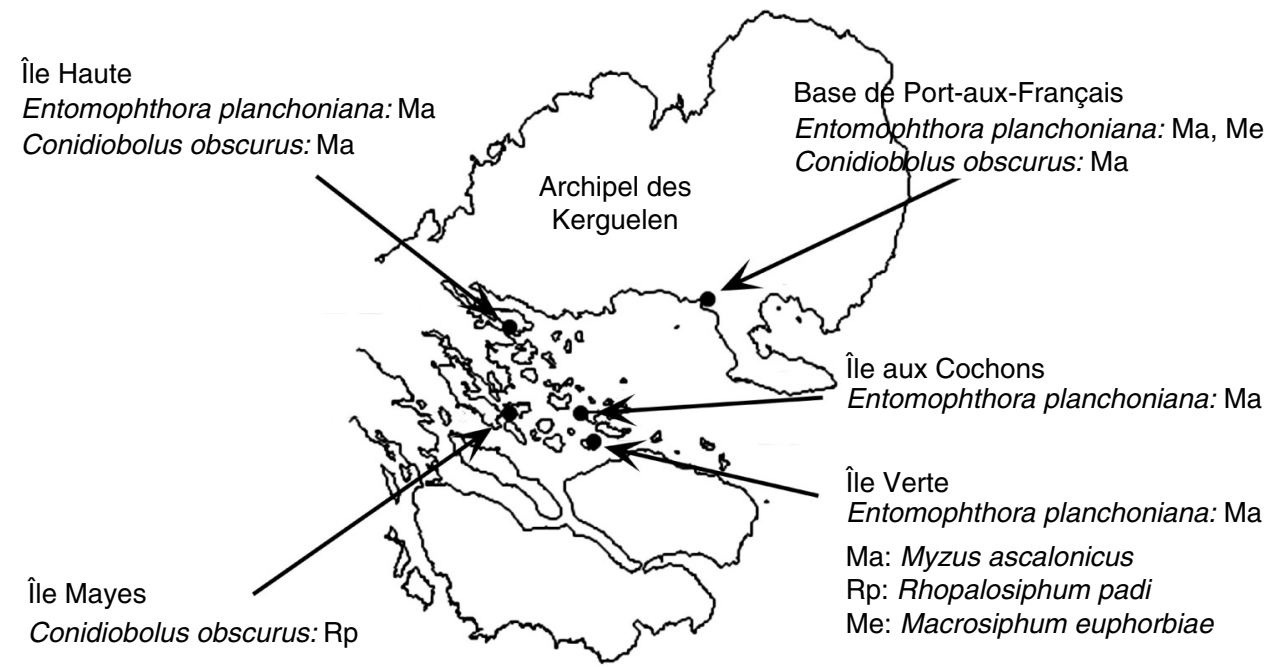

Fig. 2 Distribution of Entomophthorales in Archipel des Kerguelen (Golfe du Morbihan).

lactophenol. Shapes of spores were systematically noted, and the length and width of 10-50 spores per cadaver were measured, using a light microscope $(200 \times)$. Cadavers kept in ethanol were also mounted in anilin blue or cotton blue in lactophenol after being teased apart using fine forceps or fine insect pins for observation and measurement of possible resting spores; detailed procedures are described by, for example, Papierok and Balazy (2007). The fungal species were identified on the basis of the combination of the following phenotypic characters: shape and size of primary and possibly secondary conidia, branched or unbranched conidiophores, shape and size of resting spores, and presence and type of rhizoids (Latgé \& Papierok 1988; Keller 2006; Keller 2007).

\section{Results}

A total of 114 fungus-killed aphids were collected: 98 Myzus ascalonicus, seven Rhopalosiphum padi, seven Aulacorthum solani and two Macrosiphum euphorbiae. The distribution of entomophthoralean species and their aphid hosts are shown in Figs. 1, 2 and Table 1.
Six different Entomophthorales were distinguished from dead aphids collected on Île de La Possession, namely: Conidiobolus obscurus (Hall \& Dunn) Remaudière \& Keller (in 2001-02 and 2011-13); Entomophthora planchoniana Cornu (in 2001-02); Pandora neoaphidis (Remaudière $\delta$ Hennebert) Humber (in 2001-02); Zoophthora phalloides Batko (in 2001-02); Zoophthora sp. (in 2001-02); and Conidiobolus coronatus (Costantin) Batko (in 2011-13).

In Archipel des Kerguelen, only two species were observed (in 2011-13): Entomophthora planchoniana and Conidiobolus obscurus.

The principal morphological characteristics of these fungal species are given in Table 2, together with the sizes of the locally collected corresponding spores.

Conidiobolus obscurus was found on Myzus ascalonicus, Aulacorthum solani and Rhopalosiphum padi, but the situation differed between the two regions. On Île de la Possession, C. obscurus was observed on both periods of collection and was the main aphid pathogen at the five studied locations (57 out of 68 aphids), especially on M. ascalonicus (49 specimens out of a total of 55). In Archipel des Kerguelen, C. obscurus was found at three out of the

Table 1 The Entomophthorales and their aphid hosts. Numbers correspond to the number of collected aphids: in boldface 2001-02; in roman: 2011-13).

\begin{tabular}{|c|c|c|c|c|c|c|}
\hline \multirow[b]{2}{*}{ Entomophthorales } & \multicolumn{3}{|c|}{ Île de la Possession } & \multicolumn{3}{|c|}{ Archipel des Kerguelen } \\
\hline & $\begin{array}{c}\text { Myzus } \\
\text { ascalonicus }\end{array}$ & $\begin{array}{c}\text { Aulacorthum } \\
\text { solani }\end{array}$ & $\begin{array}{l}\text { Rhopalosiphum } \\
\text { padi }\end{array}$ & $\begin{array}{c}\text { Myzus } \\
\text { ascalonicus }\end{array}$ & $\begin{array}{c}\text { Macrosiphum } \\
\text { euphorbiae }\end{array}$ & $\begin{array}{c}\text { Rhopalosiphum } \\
\text { padi }\end{array}$ \\
\hline Conidiobolus coronatus & 1 & & & & & \\
\hline Conidiobolus obscurus & $27+22$ & 7 & 1 & 5 & & 1 \\
\hline Entomophthora planchoniana & 3 & & & 38 & 2 & \\
\hline Zoophthora phalloides & 1 & & 3 & & & \\
\hline Zoophthora sp. & 1 & & & & & \\
\hline Total & 55 & 7 & 6 & 43 & 2 & 1 \\
\hline
\end{tabular}


Table 2 The six entomophthoralean species found on aphids in Crozet and Kerguelen archipelagos: main morphological characteristics and corresponding spore sizes of the local collected material.

\begin{tabular}{|c|c|c|c|c|}
\hline $\begin{array}{l}\text { Entomophthoralean } \\
\text { species }\end{array}$ & Main morphological characteristics & $\begin{array}{l}\text { Primary conidia } \\
\text { Extreme length } \times \text { extreme } \\
\text { width in } \mu \mathrm{m}\end{array}$ & $\begin{array}{l}\text { Secondary } \\
\text { conidia } \\
\text { Length } \times \text { width } \\
\text { in } \mu \mathrm{m}\end{array}$ & Resting spores in $\mu \mathrm{m}$ \\
\hline $\begin{array}{c}\text { Conidiobolus } \\
\text { obscurus }\end{array}$ & $\begin{array}{l}\text { Unbranched conidiophores, absence of rhizoids, almost } \\
\text { globose primary conidia, spherical resting spores }\end{array}$ & $\begin{array}{l}32.7-45.7 \times 32.3-40.7 \\
\text { mean: } 40.1 \times 34.5\end{array}$ & - & $\begin{array}{l}\text { Diameter: } 34.1-34.7 \\
\text { Wall thickness: } 2.4-3.3\end{array}$ \\
\hline $\begin{array}{r}\text { Entomophthora } \\
\text { planchoniana }\end{array}$ & $\begin{array}{l}\text { Unbranched conidiophores, thick rhizoids, subspherical } \\
\text { campanulate conidia, resting spores with dark, uneven } \\
\text { epispore }\end{array}$ & $\begin{array}{c}16.7-19.0 \times 15.1-16.2 \\
\text { mean: } 18.3 \times 14.7\end{array}$ & - & $\begin{array}{l}\text { No resting spores } \\
\text { observed }\end{array}$ \\
\hline Pandora neoaphidis & $\begin{array}{l}\text { Branched conidiophores, thin rhizoids with discoid } \\
\text { holdfast, primary conidia ovoid to elongate ovoid, } \\
\text { absence of resting spores }\end{array}$ & $21.1-25.0 \times 12.6-14.9$ & - & - \\
\hline $\begin{array}{l}\text { Zoophthora } \\
\text { phalloides }\end{array}$ & $\begin{array}{l}\text { Branched conidiophores, thin rhizoids with specialized } \\
\text { holdfast, long and slim primary conidia, with a papilla } \\
\text { demarcated with a light bulge from the conidial body, } \\
\text { capilliconidia }\end{array}$ & $33.4-35.1 \times 8.7-8.9$ & $31.9 \times 8.7$ & $\begin{array}{l}\text { No resting spores } \\
\text { observed }\end{array}$ \\
\hline Zoophthora sp. & Id. but ellipsoid primary conidia & $22.8 \times 10.8$ & $23.1 \times 7.5$ & $\begin{array}{l}\text { No resting spores } \\
\text { observed }\end{array}$ \\
\hline $\begin{array}{r}\text { Conidiobolus } \\
\text { coronatus }\end{array}$ & $\begin{array}{l}\text { Unbranched conidiophores, absence of rhizoïds, almost } \\
\text { globose primary conidia, absence of resting spores, } \\
\text { presence of villose conidia }\end{array}$ & $41.2 \times 36.1$ & & - \\
\hline
\end{tabular}

five studied locations, on M. ascalonicus and R. padi only, and there were fewer of them (six out of 46 aphids).

As for C. obscurus, the situation regarding Entomophthora planchoniana differed between the two regions. On Île de la Possession, the fungus was found at one location during one period of collection (2001-02) and on three specimens of M. ascalonicus. By contrast, in Archipel des Kerguelen, E. planchoniana was observed at four out of the five locations, and was the main aphid pathogen (40 specimens out of 46), mainly on $M$. ascalonicus (38 specimens), and twice on $M$. euphorbiae at one location.

Aphids parasitized by C. obscurus and E. planchionana were found continuously between December and May, suggesting that the infection persisted over several aphid generations.

Pandora neoaphidis was collected only at Crique du Sphinx (Île de la Possession) in 2001-02 on two specimens of $R$. padi. Zoophthora phalloides was observed on Île de la Possession at two of the five studied locations, on four specimens only: three $R$. padi and one $M$. ascalonicus. From the single $M$. ascalonicus specimen found infected by $Z$. phalloides, another type of primary and secondary conidia typical from the genus Zoophthora was observed.

Unfortunately very few conidia were obtained. That material resembled Zoophthora radicans (Brefeld) Batko, but the poverty of our collection could not allow a proper identification. The fungus was therefore referred to as Zoophthora sp.
Conidiobolus coronatus was found on one occasion only on Île de la Possession, on M. ascalonicus.

\section{Discussion}

Entomophthorales are considered as the main fungal pathogens of aphids throughout the world (Latgé \& Papierok 1988; Pell et al. 2001; Barta \& Cagáň 2006). The present work is the first report of any aphid-pathogen member of that fungal group on the sub-Antarctic islands. One species of the genus Neozygites, parasitizing mites, was recorded in the west coast of Antarctica (Bridge $\&$ Worland 2004). The situation appears similar in the Arctic, where these fungi have been very rarely observed: on aphids in Finland north of the Arctic Circle (Papierok 1989), on Muscoid flies in Greenland (Eilenberg et al. 2007) and in larval populations of a noctuid moth in west Greenland (Avery \& Post 2013).

Except for Zoophthora sp., the main characteristics of the five other identified entomophthoralean species match overall the data from the literature. However, slight differences in the size of primary conidia (Conidiobolus obscurus) or length of capilliconidia (Z. phalloides) were observed compared to the literature (Remaudière et al. 1979; Bałazy 1993; Keller 2006), underlining the morphological variation within these species.

Conidiobolus obscurus and Entomophthora planchoniana, the two species most frequently found in the subAntarctic Archipel des Kerguelen and Île de la Possession, 
are two of the three most frequent and numerous pathogens in aphid populations in temperate and continental climates (Thaxter 1888; Shands et al. 1963; Gustafsson 1965; Remaudière, Latgé et al. 1981; Pell et al. 2001). The third species, P. neoaphidis, was in contrast found on one aphid species at one location only (Île de la Possession) during our investigations. One could hypothesize that this fungus was a late introduction that has not yet established itself across the archipelagos. In any case, the presence of C. obscurus in both periods of study, that is, at an interval of 10 years, shows the ability of Entomophthorales to be established successfully in the sub-Antarctic.

Entomophthora planchoniana is the most abundant species in Archipel des Kerguelen and C. obscurus on Île de la Possession. This difference in distribution could be explained by differences in rainfall between both locations, with annual rainfall much higher in Crozet than in eastern Kerguelen. In Europe, E. planchoniana seems to be able to tolerate lower relative humidity than $C$. obscurus (Dedryver 1981; Remaudière, Keller et al. 1981).

A few hypotheses can be invoked to explain the presence of Entomophthorales infecting aphids on subAntarctic islands. First, all entomophthoralean species recorded could have been introduced, along with aphids, by people. Zoophthora phalloides, for instance, is found only on aphids of the sub-family of Aphidinae, to which belong M. ascalonicus and R. padi (Remaudière, Latgé et al. 1981), the most abundant aphid species introduced in Crozet and Kerguelen (Hullé, Pannetier, Simon et al. 2003). Introduction of fungi by aphids surviving on plant foods (e.g., onions for M. ascalonicus infected by $Z$. phalloides) transported by boat appears as the most likely scenario. Second, Entomophthorales could have been introduced without human intervention by transient airborne winged aphids. Transportation of Entomophthorales by winged aphids is common, but infected aphids cannot fly actively long distances (Feng et al. 2007) and must be transported passively by wind. Longdistance passive flights by aphids (about $1300 \mathrm{~km}$ ) have been mentioned to explain the presence of the aphid Cinara abieticola Cholodkovsky in Svalbard (Heikinheimo 1968). However, the nearest possible sources of infected aphids to colonize Crozet and Kerguelen are more than $3000 \mathrm{~km}$ away, so this hypothesis seems to be less probable that the previous one to explain the presence of Entomophthorales (and of their hosts) in these archipelagos. Third, some fungal species could have been present before the arrival of aphids, on other insects or in the soil. All but one of the entomophthoralean species found in this study are aphid-specific and seem only to survive some months in soil without any aphid host (Latteur 1977). Indeed, only Conidiobolus coronatus is known to cause mortalities in other insect species (BenZe'ev \& Kenneth 1980; Papierok \& Coremans-Pelseneer 1980; Papierok 1985; Papierok et al. 1986; Keller 1987). Conidiobolus coronatus is mainly a saprophytic fungus that can be easily isolated from temperate and tropical soil samples. Although possible, this third hypothesis has not been yet supported by observations of infected insect species other than aphids or the detection of fungal material in the soil.

In conclusion, on the basis of the situation observed with the aphid-Entomophthorale model in the insular ecosystems of the sub-Antarctic archipelagos of Crozet and Kerguelen, the in-depth study of the introduction of these insects and their pathogens into such environments could contribute to a better understanding of the role of natural enemies in biological invasions (Dunn 2009).

\section{Acknowledgements}

This research was supported by the French Polar Institute (programme 136 Subanteco) and the French National Center for Scientific Research (Zone Atelier de Recherche sur l'Environnement antarctique et subantarctique). The French National Institute for Agricultural Research and the Pasteur Institute are acknowledged. We also thank scientific volunteers who helped during fieldwork.

\section{References}

Avery M. \& Post E. 2013. Record of a Zoophthora sp. (Entomophthoromycota: Entomophthorales) pathogen of the irruptive noctuid moth Eurois occulta (Lepidoptera) in west Greenland. Journal of Invertebrate Pathology 114, 292-294.

Balazy S. 1993. Flora of Poland. Fungi (Mycota). Vol. 24. Entomophthorales. Krakow: Institute of Botany.

Barta M. \& Cagáň L. 2006. Aphid-pathogenic Entomophthorales (their taxonomy, biology and ecology). Biologia 61, 543-616.

Ben-Zéev I. \& Kenneth R. G. 1980. Zoophthora phytonomi and Conidiobolus osmodes, Zygomycetes, Entomophthoraceae, two pathogens of Hypera species (Col. Curculionidae) coincidental in time and space. Entomophaga 25, 171-186.

Bridge P.D. \& Worland M.R. 2004. First report of an entomophthoralean fungus on an arthropod host in Antarctica. Polar Biology 27, 190-192.

Chown S.L., Gremmen N.J.M. \& Gaston K.J. 1998. Ecological biogeography of Southern Ocean islands: species-area relationships, human impacts, and conservation. American Naturalist 152, 562-575.

Chown S.L., Hull B. \& Gaston K.J. 2005. Human impacts, energy availability and invasion across Southern Ocean islands. Global Ecology and Biogeography 14, 521-528. 
Chown S.L., Lee J.E. \& Shaw J.D. 2008. Conservation of Southern Ocean islands: invertebrates as exemplars. Journal of Insect Conservation 12, 277-291.

Colautti R.I., Ricciardi A., Grigorovich I.A. \& MacIsaac H.J. 2004. Is invasion success explained by the enemy release hypothesis? Ecology Letters 7, 721-733.

Convey P. 2001. Terrestrial ecosystem response to climate changes in the Antarctic. In G.R. Walther, C.A. Burga, \& P.J. Edwards (eds.): "Fingerprints" of climate change-adapted behaviour and shifting species ranges. Pp. 17-42. New York: Kluwer.

Crafford J.E., Scholtz C.H. \& Chown S.L. 1986. The insects of sub-Antarctic Marion and Prince Edward islands; with a bibliography of entomology of the Kerguelen Biogeographical Province. South African Journal of Antarctic Research 16, $42-84$.

Dedryver C.A. 1981. Biologie des pucerons des céréales dans l'ouest de la France. II. Répartition spatio-temporelle et action limitative de trois espèces d'Entomophthoraceae. (Biology of cereal aphids in western France. II. Spatiotemporal distribution and limiting action of three species of Entomophthoraceae.) Entomophaga 26, 381-393.

Delmotte F., Leterme N., Bonhomme J., Rispe C. \& Simon J.C. 2001. Multiple routes to asexuality in an aphid species. Proceedings of the Royal Society of London B 268, 2291-2299.

Delmotte F., Sabater-Muñoz B., Prunier-Leterme N., Latorre A., Sunnucks P., Rispe C. \& Simon J.C. 2003. Phylogenetic evidence for hybrid origins of asexual lineages in an aphid species. Evolution 57, 1291-1303.

Dunn A.M. 2009. Parasites and biological invasions. In J.P. Webster (ed.): Natural history of host-parasite interactions. Pp. 161-184. San Diego: Elsevier.

Dunn A.M., Torchin M.E., Hatcher M.J., Kotanen P.M., Blumenthal D.M., Byers J.E., Coon C.A.C., Frankel V.M., Holt R.D., Hufbauer R.A., Kanarek A.R., Schierenbeck K.A., Wolfe L.M. \& Perkins S.E. 2012. Indirect effects of parasites in invasions. Functional Ecology 26, 1262-1274.

Eilenberg J., Schmidt N.M., Meyling N. \& Wolsted C. 2007. Preliminary survey for insect pathogenic fungi in Arctic Greenland. IOBC/WPRS Bulletin 30, 12.

Feng M., Chen C., Shang S.I., Ying S., Shen Z. \& Chen X. 2007. Aphid dispersal flight disseminates fungal pathogens and parasitoids as natural control agents of aphids. Ecological Entomology 32, 97-104.

Frenot Y., Chown S.L., Whinam J., Selkirk P.M., Convey P., Skotnicki M. \& Bergstrom D.M. 2005. Biological invasions in the Antarctic: extent, impacts and implications. Biological Reviews 80, 45-72.

Frenot Y., Gloaguen J.C., Massé L. \& Lebouvier M. 2001. Human activities, ecosystem disturbance and plant invasions in Subantarctic Crozet, Kerguelen and Amsterdam islands. Biological Conservation 101, 33-50.

Gaston K.J., Chown S.L. \& Bradley P. 2002. Invertebrate diversity and endemism at Gough Island and threats from introduced species. Final project report. Project ref. 162/8/253. Sheffield: Department of Animal and Pland Sciences, University of Sheffield.
Gustafsson M. 1965. On species of the genus Entomophthora Fres. in Sweden. I. Classification and distribution. Lantbrukshögskolans Annaler 31, 103-212.

Hayes K. \& Barry S. 2008. Are there any consistent predictors of invasion success? Biological Invasions 10, 483-506.

Heikinheimo O. 1968. The aphid fauna of Spitsbergen. Annales Entomologici Fennici 34, 82-93.

Hullé M. 2012. Myzus ascalonicus, an aphid recently introduced to sub-Antarctic islands, prefers native to exotic host-plants. Environmental Entomology 41, 1398-1404.

Hullé M., Pannetier D., Maurice D., Courmont L., Chaillon C., Chaillon P.-E., Saccone P., Hébert C., Gracia M., Buffin J., Simon J.-C. \& Frenot Y. 2003. Aphids from Kerguelen and Crozet Islands, Subantarctic. In A.H.L. Huiskes et al. (eds.): Antarctic biology in a global context. Pp. 308-312. Leiden: Backhuys Publishers.

Hullé M., Pannetier D., Simon J.-C., Vernon P. \& Frenot Y. 2003. Aphids of sub-Antarctic Îles Crozet and Kerguelen: species diversity, host range and spatial distribution. Antarctic Science 15, 203-209.

Keller S. 1987. Arthropod-pathogenic Entomophthorales of Switzerland. I. Conidiobolus, Entomophaga and Entomophthora. Sydowia 40, 122-167.

Keller S. 2006. Entomophthorales attacking aphids with a description of two new species. Sydowia 58, 38-74.

Keller S. 2007. Systematics, taxonomy and identification. In S. Keller (ed.): Arthropod-pathogenic Entomophthorales: biology, ecology and identification. Pp. 111-126. Luxembourg: Office for Official Publications of the European Communities.

Latgé J.P. \& Papierok B. 1988. Aphid pathogens. In A.K. Minks \& P. Harrewijn (eds.): Aphids: their biology, natural enemies and control. Pp. 323-335. Amsterdam: Elsevier.

Latteur G. 1977. Sur la possibilité d'infection directe d'aphides par Entomophthora à partir de sols hébergeant un inoculum naturel. (The possibility of direct infection of aphids by Entomophthora from soil natural inoculum.) Comptes Rendus des Séances de l'Académie des Sciences de Paris 284, 2253-2256.

Lebouvier M. \& Frenot Y. 2007. Conservation and management in the French sub-Antarctic islands and surrounding seas. Papers and Proceedings of the Royal Society of Tasmania 141, 23-28.

Lebouvier M., Laparie M., Hullé M., Marais A., Cozic Y., Lalouette L., Vernon P., Candresse T., Frenot Y. \& Renault D. 2011. The significance of the sub-Antarctic Kerguelen Islands for the assessment of the vulnerability of native communities to climate change, alien insect invasions and plant viruses. Biological Invasions 13, 1195-1208.

Liu H. \& Stiling P. 2006. Testing the enemy release hypothesis: a review and meta-analysis. Biological Invasions 8, 1535 1545.

Papierok B. 1985. Données écologiques et expérimentales sur les potentialités entomopathogènes de l'Entomophthorale Conidiobolus coronatus (Costantin) Batko. (Ecological and experimental data on the insect pathogenic potential of the Entomophthorale Conidiobolus coronatus.) Entomophaga $30,303-312$. 
Papierok B. 1989. On the occurrence of Entomophthorales in Finland. I. Species attacking aphids (Homoptera, Aphididae). Annales Entomologici Fennici 55, 63-69.

Papierok B., Aeschlimann J. P. \& Loan C. 1986. Two entomophthoralen fungi occuring on Hypera postica in southern France. Journal of Invertebrate Pathology 48, 377-380.

Papierok B. \& Balazy S. 2007. Collecting arthropod-pathogenic Entomophthorales: how to find them in the field and how to collect, prepare and store the appropriate material for classical identification purpose? In S. Keller (ed.): Arthropodpathogenic Entomophthorales: biology, ecology and identification. Pp. 57-65. Luxembourg: Office for Official Publications of the European Communities.

Papierok B. \& Coremans-Pelseneer J. 1980. Contribution á l'étude de Conidiobolus osmodes Dreschler (Zygomycètes, Entomophthoraceae), agent occasionel d'épizooties chez les Pucerons (Homoptères Aphididae). (Contribution to the study of Conidiobolus osmodes Drechsler [Zygomycetes, Entomophthora Cae], occasional epizootic in aphids [Homoptera Aphididae].) Cryptogamie Mycologie 1, 111-117.

Pell J.K., Eilenberg J., Hajek A.E. \& Steinkraus D.C. 2001. Biology, ecology, and pest management potential of Entomophthorales. In T.M. Butt et al. (eds.): Fungi as biological agents: progress, problems and potential. Pp. 71-153. Wallingford: CABI Publishing.

Prenter J., MacNeil C., Dick J.T.A. \& Dunn A.M. 2004. Roles of parasites in animal invasions. Trends in Ecology \& Evolution $19,385-390$.

Remaudière G. \& Etienne J. 1988. Les Aphididae (Hom.) des îles et archipels de l'océan Indien. (Aphididae [Hom.] of the Indian Oceanic islands and archipelagos.) L'agronomie Tropicale 43, 327-346.

Remaudière G., Keller S., Papierok B. \& Latgé J.-P. 1981. Considérations systématiques et biologiques sur quelques espèces d'Entomophthora du groupe pathogènes d'insectes (Phycomyctes: Entomophthoraceae). (Systematic and biological considerations regarding some Entomophthora species of insect pathogens [Phycomyctes: Entomophthoraceae].) Entomophaga 21, 163-177.

Remaudière G., Latgé J.-P. \& Michel M.F. 1981. Ecologie comparée des entomophthoracées pathogènes de pucerons en France littorale et continentale. (Ecology of aphid pathogenic Entomophthorales in coastal and continental France.) Entomophaga 26, 157-178.

Remaudière G., Latgé J.-P. \& Papierok B. 1979. Reconsidération taxonomique de Entomophthora obscura Hall \& Dunn. (Taxonomic revision of Entomophthora obscura Hall \& Dunn. Annales de Microbiologie (Institut Pasteur) 130A, $151-162$.

Shands W.A., Simpson G.W. \& Hall I.M. 1963. Importance of entomogenous aphids in controlling aphids on potatoes in northeastern Maine. Maine Agricultural Experimental Station Technical Bulletin 6. Orono: Maine Agricultural Experiment Station.

Svanella-Dumas L., Candresse T., Hullé M. \& Marais A. 2013. Distribution of barley yellow dwarf virus-PAV in the subAntarctic Kerguelen Islands and characterization of two new luteovirus species. PLoS One 8, e67231, doi: http://dx. doi.org/10.1371/journal.pone.0067231

Thaxter R. 1888. The Entomophthoreae of the United States. Memoirs of the Boston Society of Natural History 4(6), 133-201.

Torchin M.E., Lafferty K.D., Dobson A.P., McKenzie V.J. \& Kuris A.M. 2003. Introduced species and their missing parasites. Nature 421, 628-630.

Vernon P., Vannier G. \& Trehen P. 1998. A comparative approach to the entomological diversity of polar regions. Acta Oecologica 19, 303-308. 